\title{
Red Light-initiated Crosslinking of NIR Probes to Cytoplasmic RNA: An Innovative Strategy for Prolonged Imaging and Unexpected Tumor Suppression
}

Shuyue Ye, ${ }^{\ddagger}$ Chaoxiang Cui, ${ }^{\ddagger}$ Xiaju Cheng, ${ }^{\S}$ Meng Zhao,${ }^{\ddagger}$ Qiulian Mao,${ }^{\ddagger}$ Yuqi Zhang, ${ }^{\ddagger}$ Anna Wang, ${ }^{\star}$ Jing Fang, ${ }^{\star}$ Yan Zhao, ${ }^{\star}$ Haibin Shi*,

FState Key Laboratory of Radiation Medicine and Protection, School for Radiological and Interdisciplinary Sciences (RAD-X) and Collaborative Innovation Center of Radiation Medicine of Jiangsu Higher Education Institutions, Soochow University, Suzhou 215123, P. R. China

SJiangsu Key Laboratory of Infection \& Immunity, Institutes of Biology \& Medical Sciences, Soochow University, Suzhou 215123, P. R. China

\section{Table of Contents}

Materials and Synthesis

Supplementary Schemes, Tables and Figures.

Scheme S1. Synthetic routes for $f-C R$ and its control CR.

Scheme S2. The method of extracting cell total RNA, cytoplasmic and nuclear RNA.

Scheme S3. Schematic illustration of tumor suppression experimental approach after probe crosslinking reaction in tumor tissue until 13 days.

Table S1. RNA information.

Figure S1. HR-MS spectrum of 1.

Figure S2. HR-MS spectrum of 2.

Figure S3. HR-MS spectrum of 3.

Figure S4. HR-MS spectrum of $f$-CR.

Figure S5. HR-MS spectrum of CR.

Figure S6. The absorption and emission spectra of CR and Cy7. 
Figure S7. Hydrodynamic size profile of $f$-CR nanoparticles in PBS $(\mathrm{pH}=7.4)$.

Figure S8. UV-Vis absorption spectra of $f-C R$ in a mixed solvent of PBS and DMSO.

Figure S9. TEM characteristics and size distribution of CR.

Figure S10. Mass spectrometry of compounds before and after the crosslinking reaction of RNA and $f$-CR.

Figure S11. RNA gel electrophoresis treated with different concentrations of MB.

Figure S12. Confocal microscopy images and normalized signal intensity of 3T3 cells, 4T1 cells incubated with the $f$-CR.

Figure S13. Cellular uptake of $C R$ and $f-C R$ by $4 T 1$ cell after different incubation time.

Figure S14. Cell viability of 4T1 cell treated with various doses of MB under $660 \mathrm{~nm}$ light irradiation.

Figure S15. Fluorescent image of $4 \mathrm{~T} 1$ cells treated with different dose of MB irradiated with $660 \mathrm{~nm}$ light.

Figure S16. Confocal microscopy images and Pearson coefficient of 4T1 cells treated with different dose of $\mathrm{MB}$ and $f-\mathrm{CR}$.

Figure S17. Fluorescence spectra of each group of cytoplasmic RNA.

Figure S18. Fluorescence pictures of EB and Cy7 under gel electrophoresis of RNA extracted from the nucleus of $4 \mathrm{~T} 1$ cells.

Figure S19. The PAGE gel pictures of $4 \mathrm{~T} 1$ cell total protein under coomassie blue and Cy 7.

Figure S20. Fluorescence imaging of tumor section DHE stains after intratumoral injection of $\mathrm{MB}$.

Figure S21. In vivo fluorescence images of subcutaneous 4T1 tumor-bearing Balb/c female mice with intratumoral post injection of MB and intravenous injection of $f$-CR or $C R$. Figure S22. Live-cell differential interface contrast imaging of $4 \mathrm{~T} 1$ cells after treatment with $\mathrm{CR}, f-\mathrm{CR}$.

Figure S23. Flow cytometry imaging and apoptosis level of $4 \mathrm{~T} 1$ cells after treatment with $\mathrm{CR}, f-\mathrm{CR}$.

Figure S24. The mice photos of day 1, 3, 5, 7, 9, 11 after treatment. 
Figure S25. The average weight of various groups tumors after 13 days of treatment. 


\section{Materials and Synthesis}

Synthesis of compound 1. Boc-Lys (Fmoc)-OH $(0.5 \mathrm{~g}, 1.07 \mathrm{mmol})$ was dissolved in a mixture of DCM $(10 \mathrm{~mL})$ and TFA $(2 \mathrm{~mL})$ to remove Boc at room temperature for $10 \mathrm{~min}$ and the mixture followed by concentration under reduced pressure and obtained white solid mixture. Then 3-(2-furyl) propanoic acid (0.2 g, $1.43 \mathrm{mmol})$, 1-(3-Dimethylaminopropyl)-3ethylcarbodiimide hydrochloride $(0.82 \mathrm{~g}, 1.43 \mathrm{mmol})$ and $\mathrm{N}$-hydroxysuccinimide $(0.2 \mathrm{~g}$, $1.71 \mathrm{mmol})$ were dissolved in dry DMF $(10 \mathrm{~mL})$ and added in above-mentioned mixture, after stirred for $4 \mathrm{~h}$ at room temperature $\mathrm{N}, \mathrm{N}$-diisopropylethylamine $(5 \mu \mathrm{L})$ were added for additional $3 \mathrm{~h}$. Then, the reaction was concentrated under reduced pressure, and further washed by EA ( $20 \mathrm{~mL} X 3)$, dried over anhydrous $\mathrm{NaSO}_{4}$. The crude product was purified by chromatography $\left(\mathrm{SiO}_{2} ; \mathrm{EA} / \mathrm{PE}=4: 1, \mathrm{v} / \mathrm{v}\right)$ to obtained $1(0.56 \mathrm{~g}, 80 \%)$ as orangey solid. Calcd. for, $\mathrm{C}_{28} \mathrm{H}_{30} \mathrm{~N}_{2} \mathrm{O}_{6}\left([\mathrm{M}+\mathrm{H}]^{+}\right)$: 489.2021, found ESI-MS: m/z 489.2031.

Synthesis of compound 2. cRGD (10 mg, $16.57 \mu \mathrm{mol})$ and $1(19.47 \mathrm{mg}, 33.13 \mu \mathrm{mol})$ were dissolved in dry DMF $(5 \mathrm{~mL})$ with constant stirring for 10 min at $0^{\circ} \mathrm{C}$ and slowly drooped $\mathrm{N}, \mathrm{N}$-diisopropylethylamine $(2 \mu \mathrm{L})$ at same time. Then the mixture was cooled down to room temperature, and was further stirred for $2 \mathrm{~h}$. The mixture was concentrated under reduced pressure. Then, the mixture was further diluted with water/acetonitrile ( 5 $\mathrm{mL}, 1: 1, \mathrm{v} / \mathrm{v}$ ) containing $0.1 \%$ TFA purified by preparative HPLC at the following conditions: flow rate of $10 \mathrm{~mL} / \mathrm{min}$ for $40 \mathrm{~min}$ from $5 \%$ acetonitrile to $100 \%$ acetonitrile and absorption channel at $254 \mathrm{~nm}$. The product concentrated under lyophilized and got white solid. Calcd. for, $\left.\mathrm{C}_{55} \mathrm{H}_{69} \mathrm{~N}_{11} \mathrm{O}_{12}([\mathrm{M}-\mathrm{H}]]^{-}\right): 1076.5190$, found ESI-MS: m/z 1076.5187.

Synthesis of compound 3. 2 (10 mg, $9.29 \mu \mathrm{mol})$ was dissolved in DMF/diethylamine $(6 \mathrm{~mL}, 5: 1, \mathrm{v} / \mathrm{v})$, which was stirred at room temperature for $1 \mathrm{~h}$. The mixture was concentrated under reduced pressure. Then, the mixture was further diluted with water/acetonitrile $(5 \mathrm{~mL}, 1: 1, \mathrm{v} / \mathrm{v})$ containing $0.1 \%$ TFA purified by preparative HPLC at the following conditions: flow rate of $10 \mathrm{~mL} / \mathrm{min}$ for $40 \mathrm{~min}$ from $5 \%$ acetonitrile to $100 \%$ acetonitrile and absorption channel at $214 \mathrm{~nm}$. Then, the product concentrated under lyophilized and got white solid. Calcd. for, $\mathrm{C}_{40} \mathrm{H}_{59} \mathrm{~N}_{11} \mathrm{O}_{10}\left([\mathrm{M}-\mathrm{H}]^{-}\right)$: 852.4374 , found ESI-MS: $\mathrm{m} / \mathrm{z} 852.4370$. 
Synthesis of compound f-CR. $3(5 \mathrm{mg}, 5.86 \mu \mathrm{mol})$, Cy7-SE $(4.24 \mathrm{mg}, 5.86 \mu \mathrm{mol})$ were dissolved in dry DMF $(2 \mathrm{~mL})$, which was stirred for $10 \mathrm{~min}$ at $0^{\circ} \mathrm{C}$ and slowly drooped $\mathrm{N}, \mathrm{N}$-diisopropylethylamine $(0.5 \mu \mathrm{L})$ as well. Then the mixture was warmed to room temperature, it was further stirred for $2 \mathrm{~h}$. Then, the mixture was further diluted with water/acetonitrile $(5 \mathrm{~mL}, 1: 1, \mathrm{v} / \mathrm{v})$ containing $0.1 \%$ TFA purified by preparative HPLC at the following conditions: flow rate of $10 \mathrm{~mL} / \mathrm{min}$ for $40 \mathrm{~min}$ from $5 \%$ acetonitrile to $100 \%$ acetonitrile and absorption channel at $750 \mathrm{~nm}$. Then, the product was concentrated under lyophilized and afford blue solid. Calcd. for, $\mathrm{C}_{75} \mathrm{H}_{99} \mathrm{~N}_{13} \mathrm{O}_{17} \mathrm{~S}_{2}\left([\mathrm{M}-\mathrm{H}]^{-}\right)$: 1516.6651 , found ESI-MS: m/z 1516.6664 .

Synthesis of compound CR. CRGD (5 mg, $8.27 \mu \mathrm{mol})$, Cy7-SE (5.99 mg, $8.27 \mu \mathrm{mol})$ were dissolved in dry DMF $(2 \mathrm{~mL})$ and slowly drooped N, N-diisopropylethylamine $(0.5 \mu \mathrm{L})$, which was stirred for 10 min at $0^{\circ} \mathrm{C}$. Then, the mixture was cooled down to room temperature and stirred for further $2 \mathrm{~h}$. The reaction solution concentrated under reduced pressure, and the mixture was diluted with water/acetonitrile $(5 \mathrm{~mL}, 1: 1, \mathrm{v} / \mathrm{v})$ containing $0.1 \%$ TFA purified by preparative HPLC at the following conditions: flow rate of $10 \mathrm{~mL} / \mathrm{min}$ for 40 min from $5 \%$ acetonitrile to $100 \%$ acetonitrile and absorption channel at $750 \mathrm{~nm}$. Then, the product was concentrated under lyophilized and gave blue solid. Calcd. for, $\left.\mathrm{C}_{62} \mathrm{H}_{81} \mathrm{~N}_{11} \mathrm{O}_{14} \mathrm{~S}_{2}([\mathrm{M}-\mathrm{H}]]^{-}\right): 1266.5339$, found ESI-MS: m/z 1266.5321. 
Supplementary Schemes, Tables and Figures.
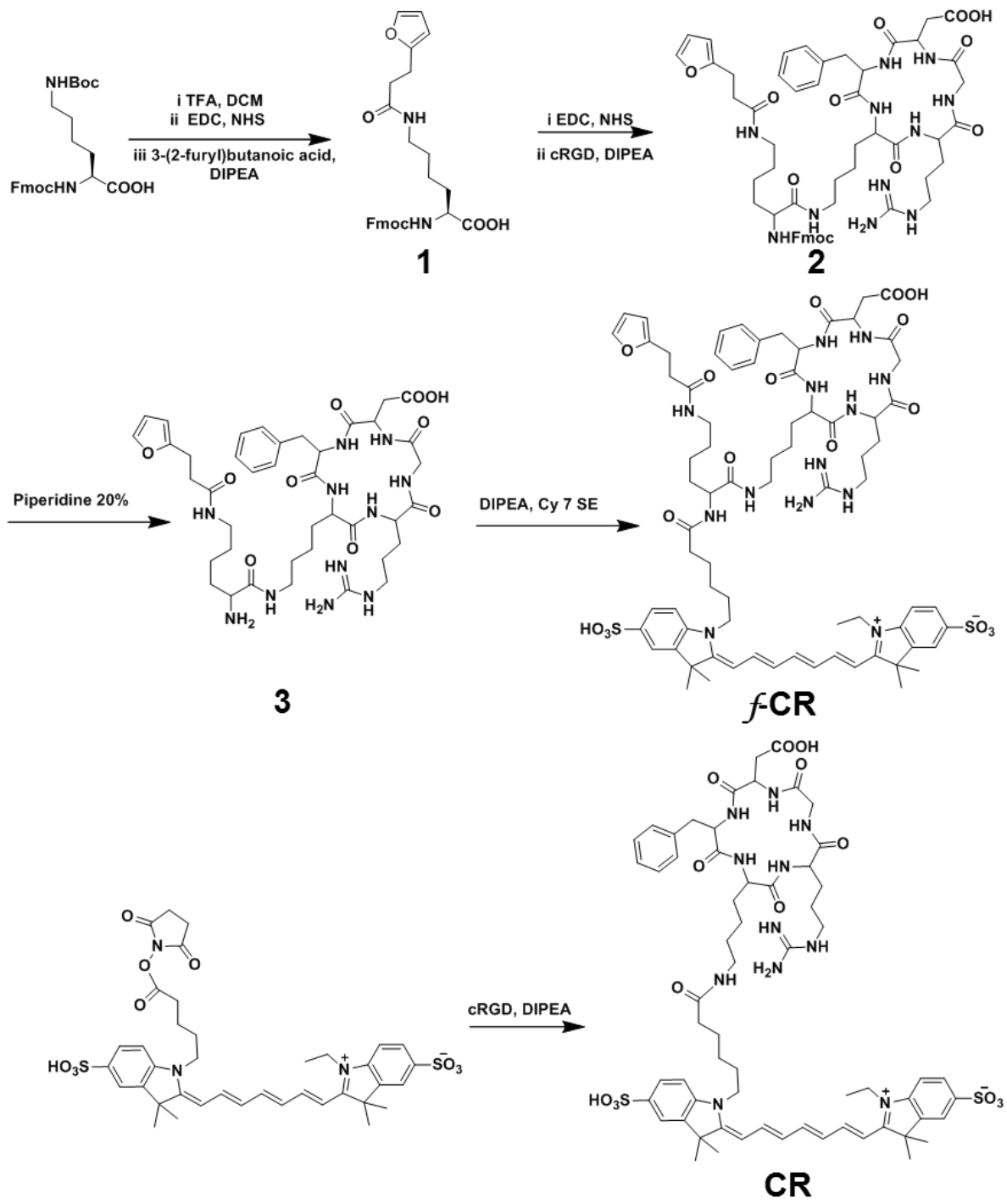

Scheme S1. Synthetic routes for $f$-CR and its control CR. 


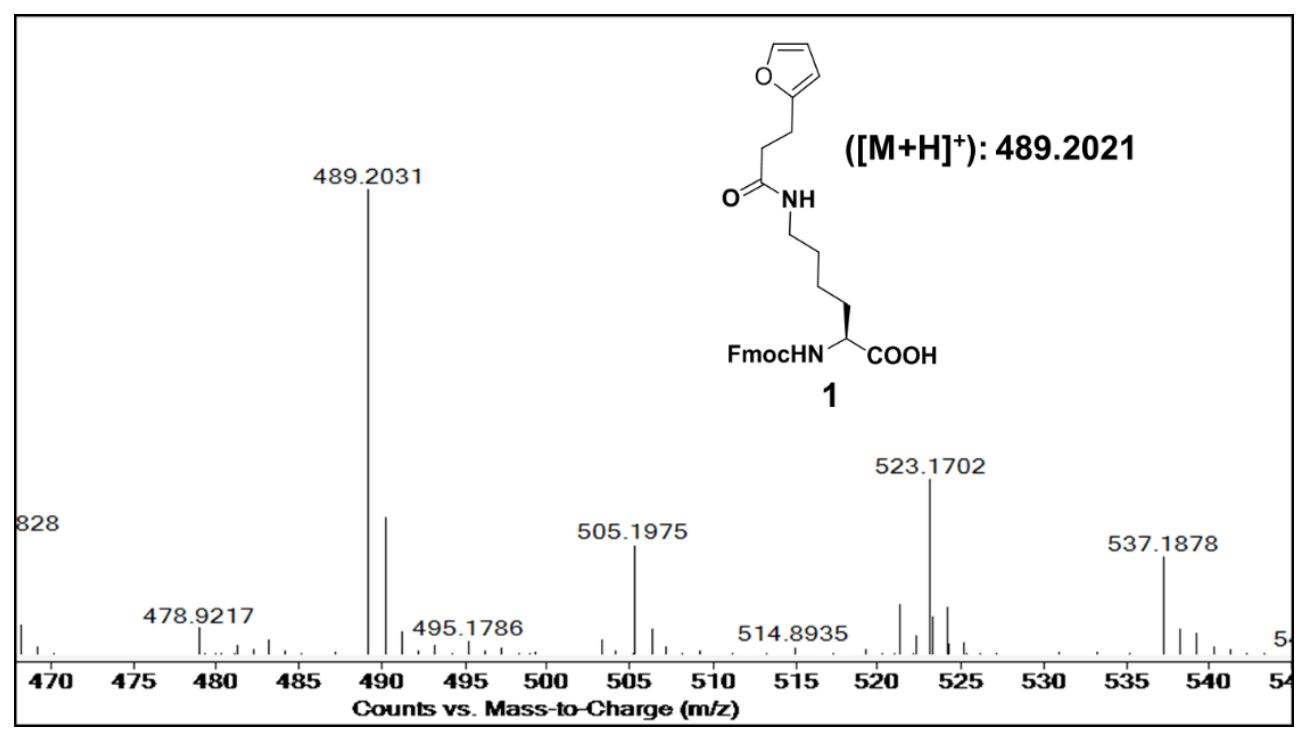

Figure S1. HR-MS spectrum of 1.

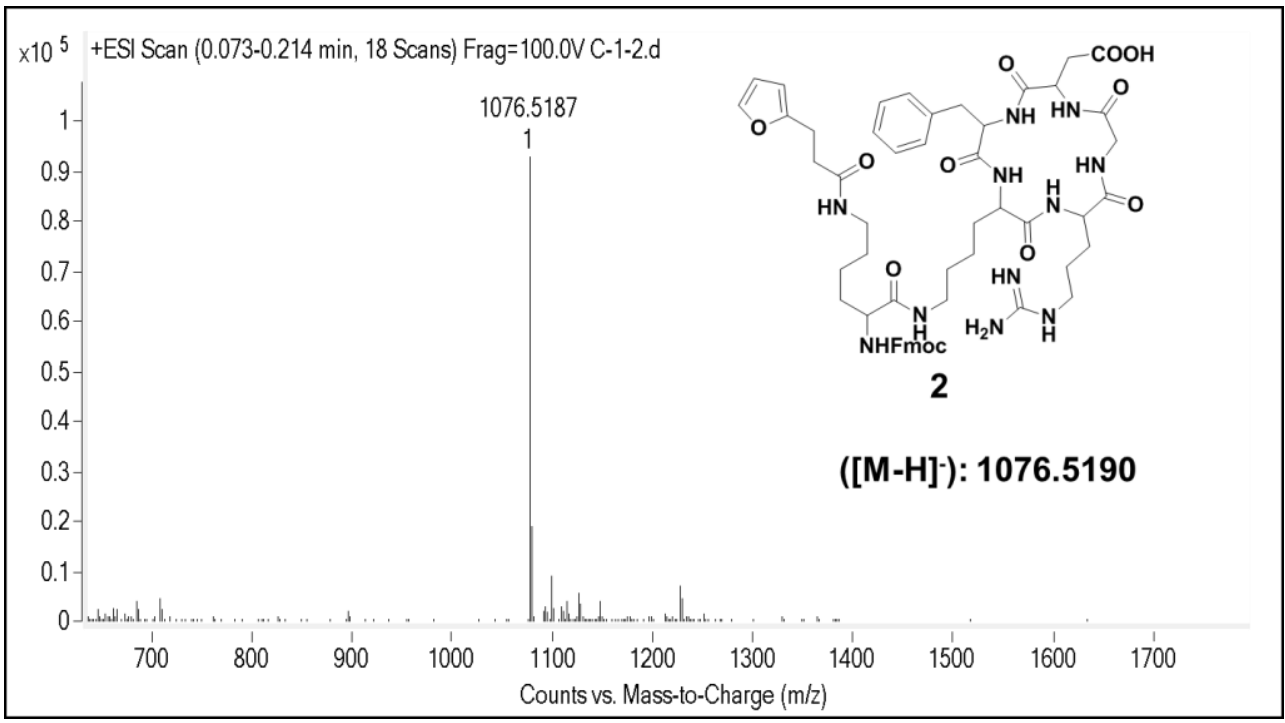

Figure S2. HR-MS spectrum of 2. 


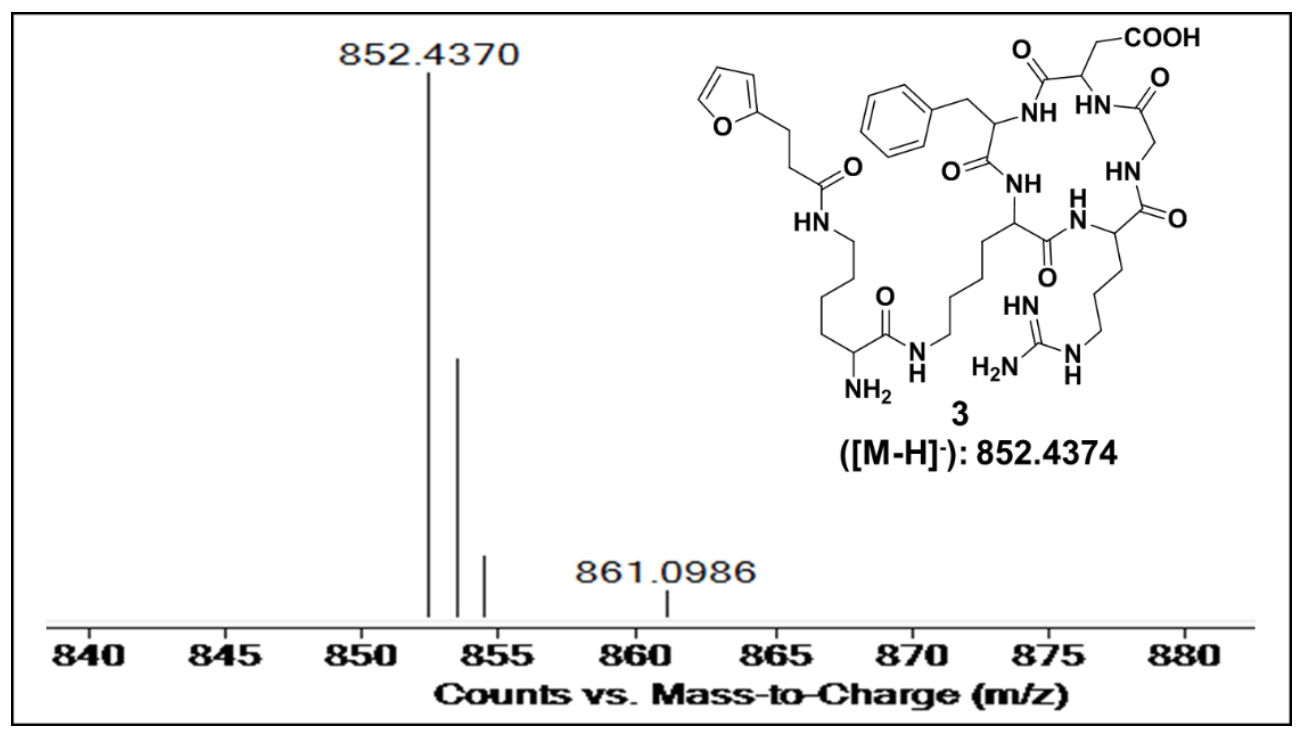

Figure S3. HR-MS spectrum of 3.

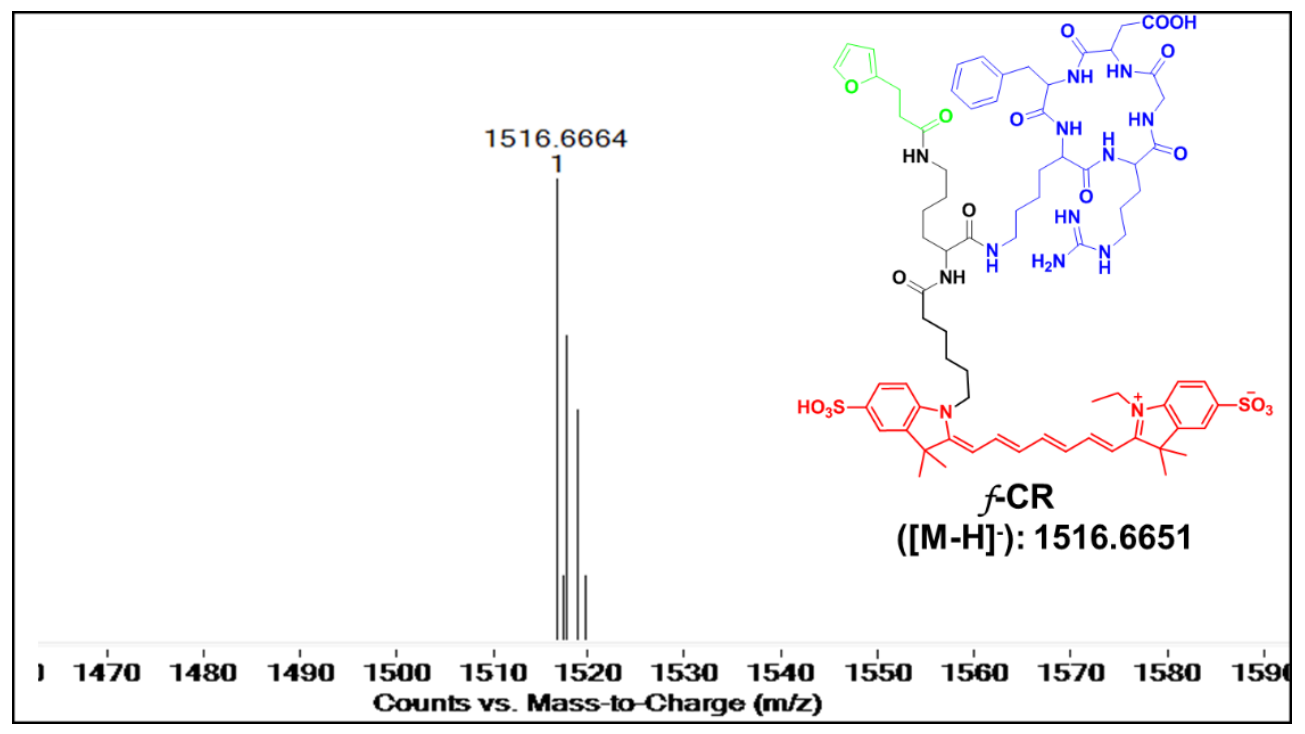

Figure S4. HR-MS spectrum of $f-C R$. 


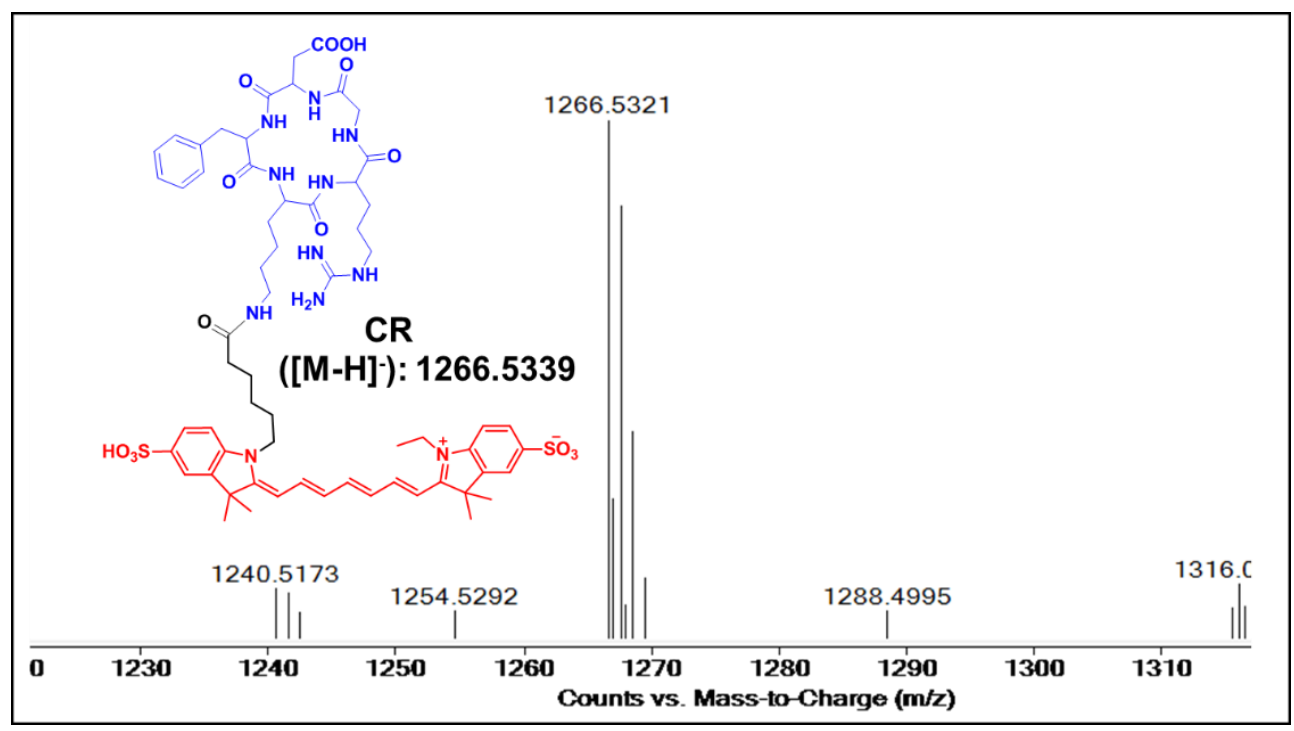

Figure S5. HR-MS spectrum of CR.
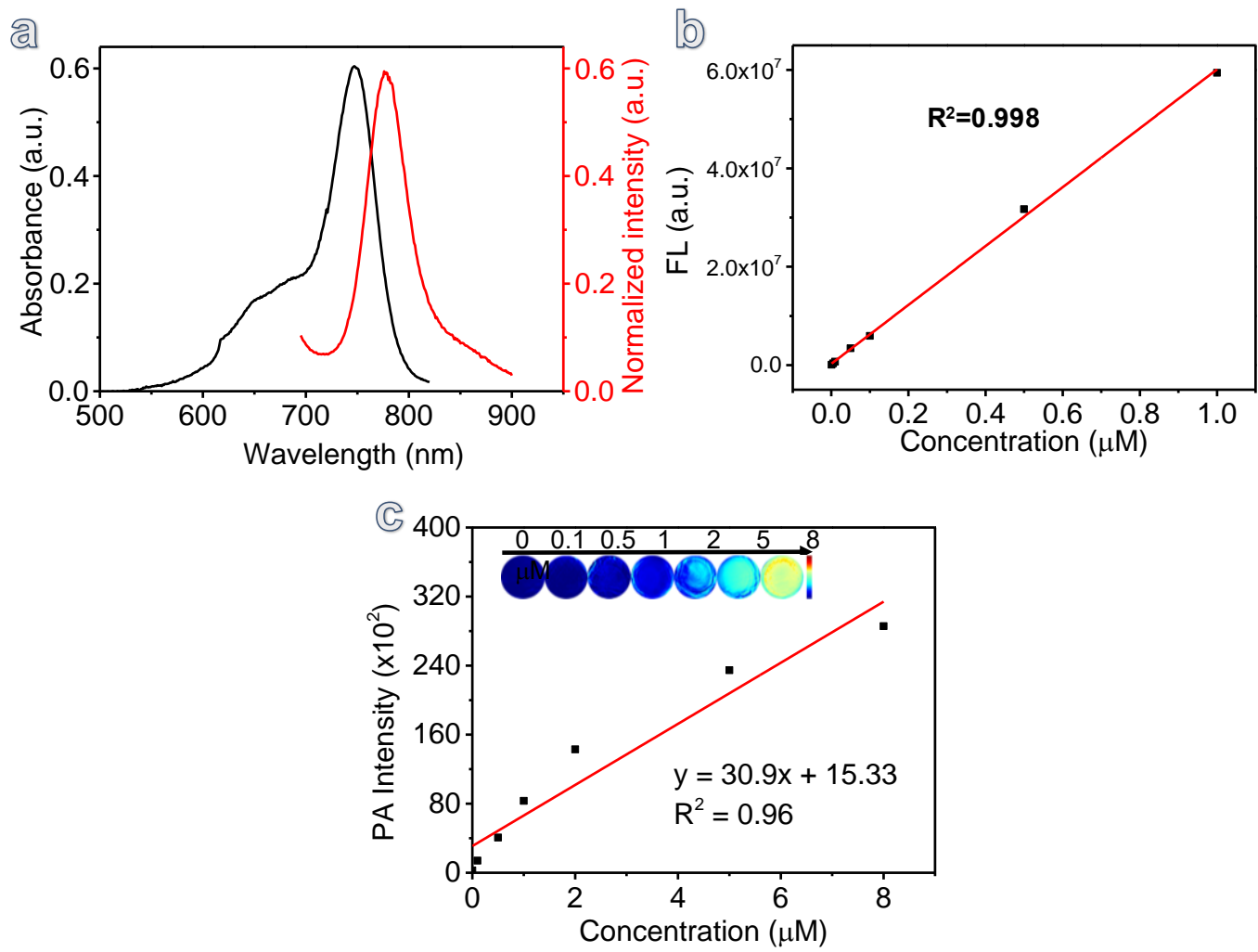

Figure S6. The absorption and emission spectra of CR $(10 \mu \mathrm{M})$ in water (a) and the fluorescence standard curve (b) of Cy7 at different concentrations $(0.001,0.005,0.01,0.05$, $0.1,0.5$ and $1 \mu \mathrm{M})(\mathrm{y}=226839.20454 \mathrm{x}-4775.63542)$. Linearity curve of $\mathrm{PA}$ intensity various concentration of $f$-CR $(0,0.1,0.5,1,2,5,8 \mu \mathrm{M})(\mathrm{c})$. 


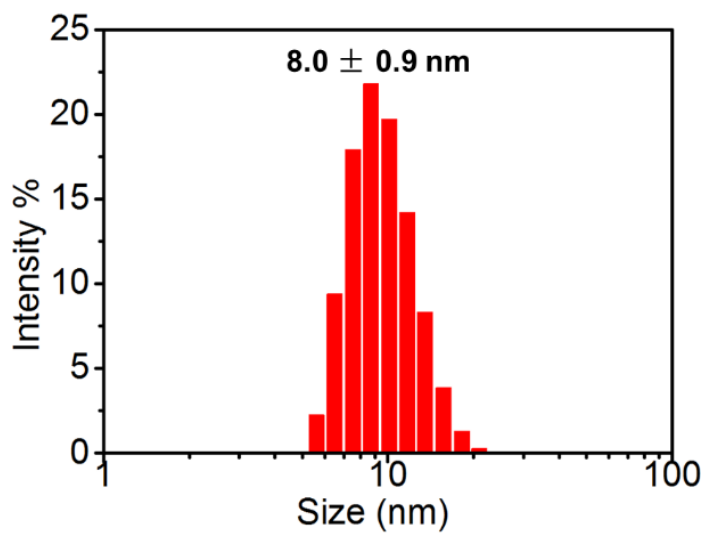

Figure S7. Hydrodynamic size profile of $f$-CR $(20 \mu \mathrm{M})$ nanoparticles in PBS $(\mathrm{pH}=7.4)$.

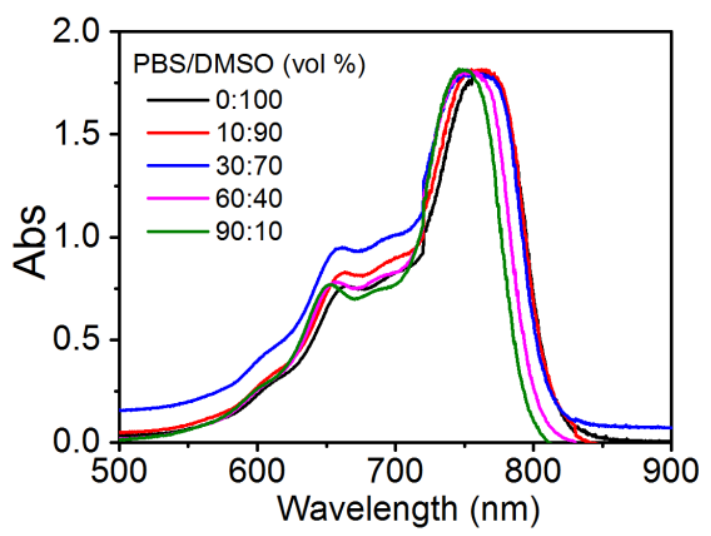

Figure S8. UV-Vis absorption spectra of the $f-C R(20 \mu \mathrm{M})$ in solutions formed by PBS $(\mathrm{pH}=7.4)$ and $\mathrm{DMSO}$ with different volume ratios.

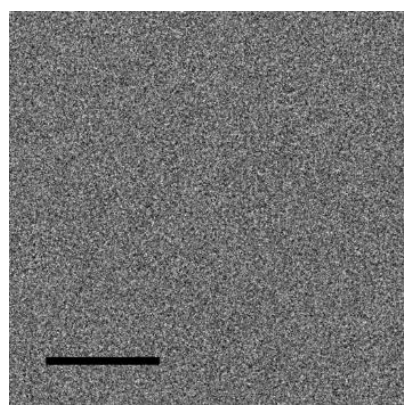

Figure S9. TEM characteristics and size distribution of CR (Scale bar $=20 \mathrm{~nm})$. 

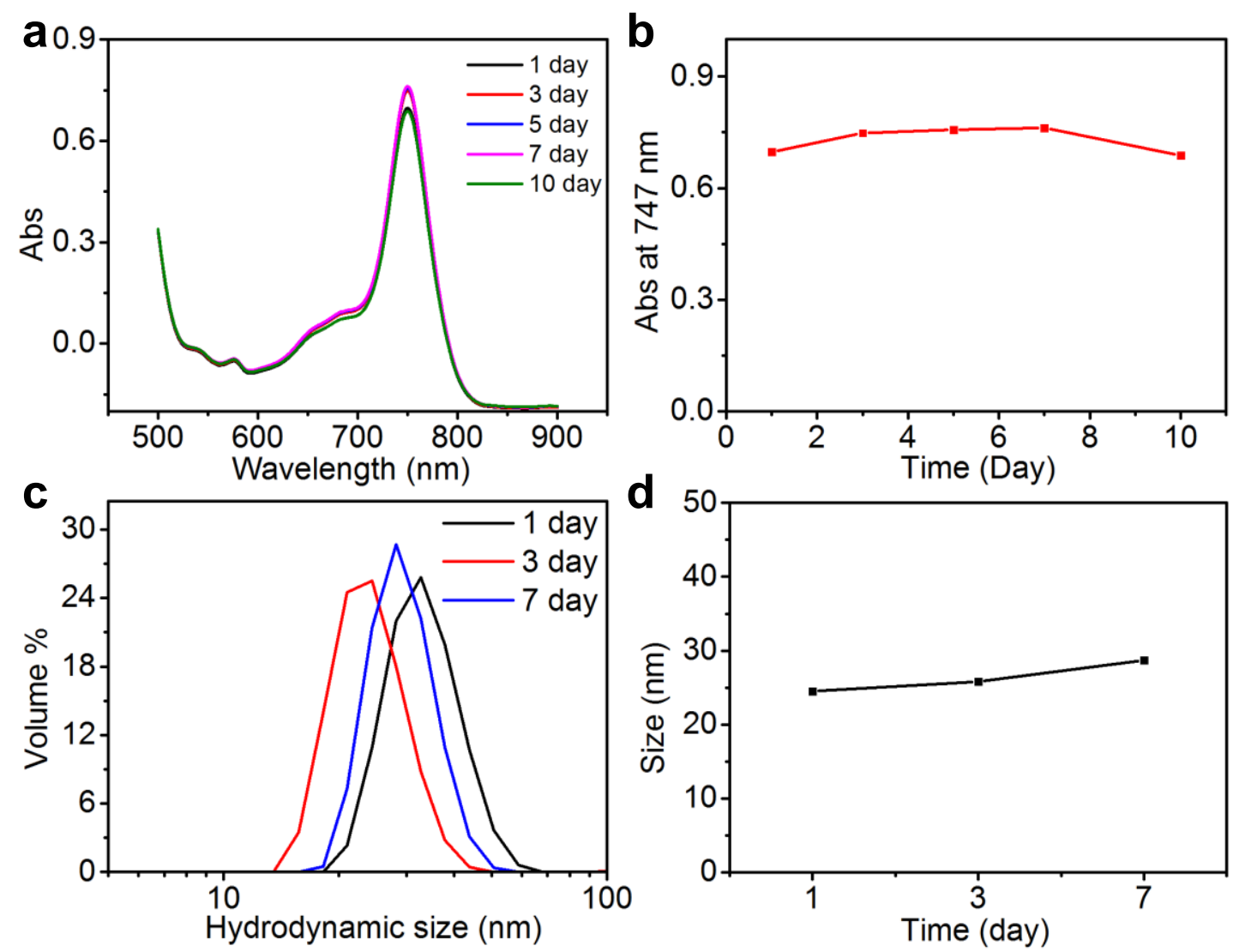

Figure S10. The UV-Vis absorption spectra (a) and absorbance at 727nm (b) of $f$-CR (10 $\mu \mathrm{M})$ in serum solution at diferent time points (1, 3, 5, 7 and 10 days). (c and d) hydrodynamic size profiles of $f$-CR $(50 \mu \mathrm{M})$ probe in PBS with $10 \%$ serum.

\begin{tabular}{|l|l|c|}
\hline Name & Sequence & MW or Length \\
\hline Single-stranded & $\left(5^{\prime}-3^{\prime}\right):$ & 10692.9 \\
small RNA & ACAUCGGGAUAGCGA & \\
& AGUUGAGAGAGAGGG & \\
& AG & \\
\hline GFP-mRNA & & $996 \mathrm{nt}$ \\
\hline
\end{tabular}

Table S1. Information on model RNA. 

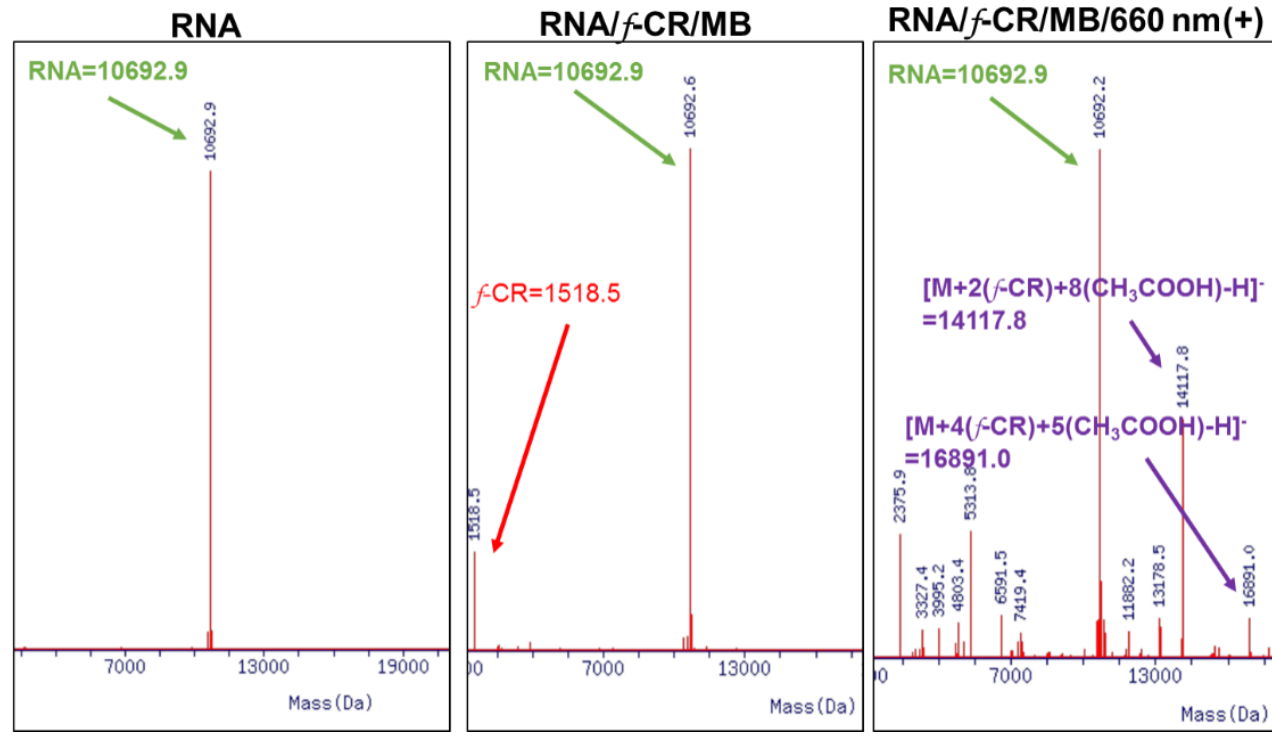

Figure S11. Mass spectrometry analysis of the molecular weight changes before (middle) and after (right) crosslinking between RNA and $f$-CR. ([RNA] $=[f-C R]=[M B]=10 \mu \mathrm{M}, 660 \mathrm{~nm}$ : $\left.50 \mathrm{~mW} / \mathrm{cm}^{2}, 2 \mathrm{~min}\right)$.

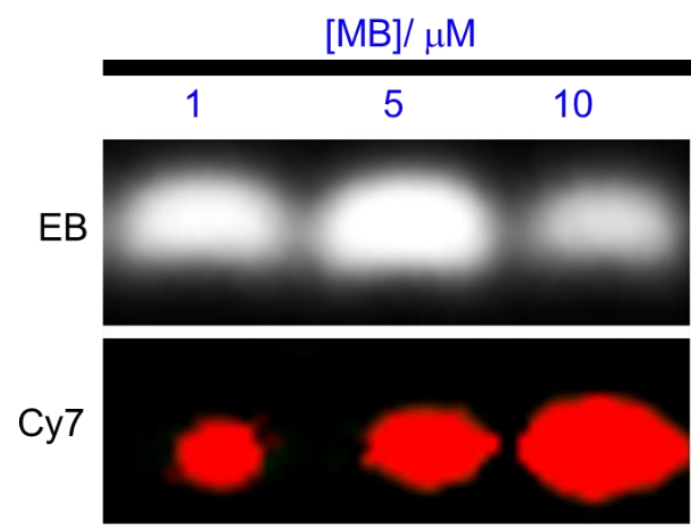

Figure S12. RNA gel electrophoresis to investigate the cross-linking efficiency of RNA (10 $\mu \mathrm{M})$ and $f$-CR $(10 \mu \mathrm{M})$ with different concentrations of $\mathrm{MB}(1 \mu \mathrm{M}, 5 \mu \mathrm{M}$, and $10 \mu \mathrm{M})$ under $660 \mathrm{~nm}$ laser light (50 mW/cm², $2 \mathrm{~min}$ ). 


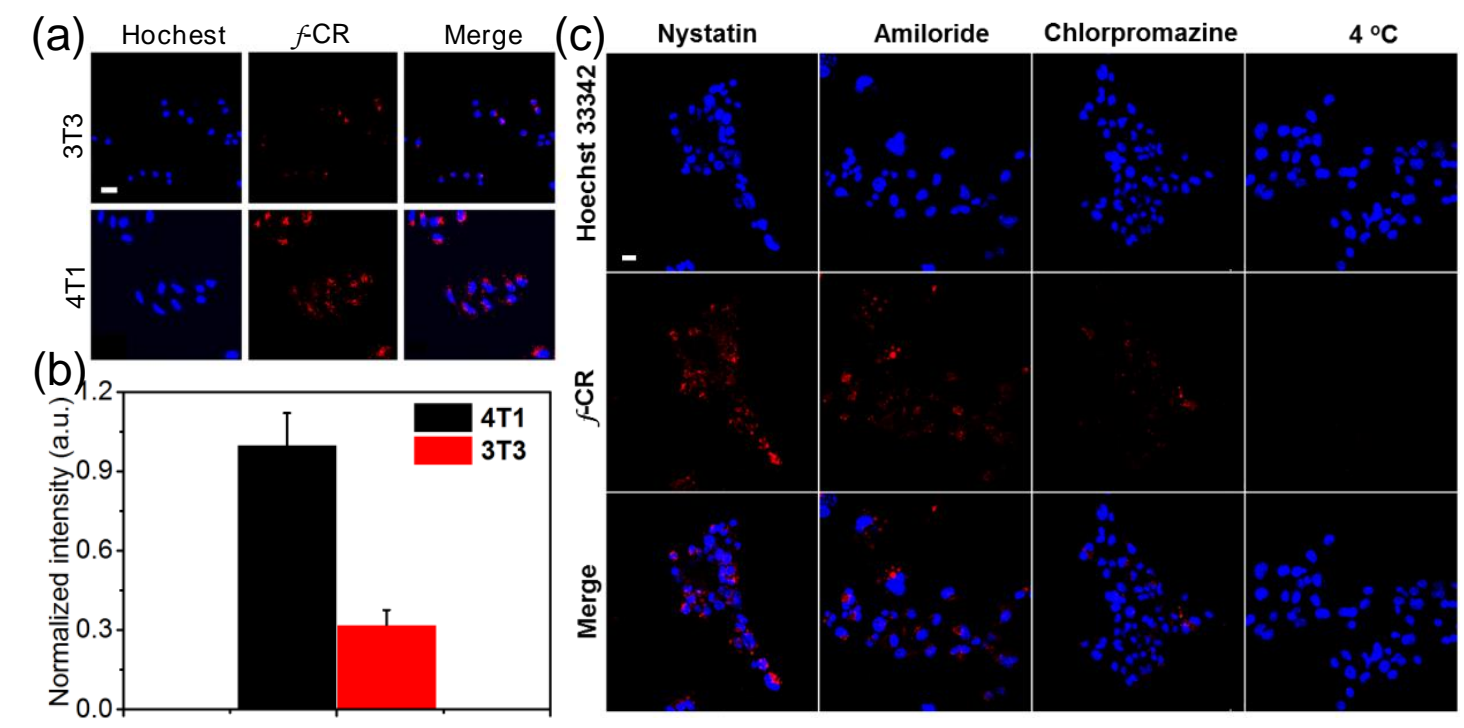

Figure S13. Confocal microscopy images (a) and normalized signal intensity (b) of 3T3 cells, $4 \mathrm{~T} 1$ cells incubated with the $f$-CR $(5 \mu \mathrm{M})$ for $3 \mathrm{~h}$. Scale bar: $20 \mu \mathrm{m}$.(c) CLSM images of endocytosis-based uptake of probe $f$-CR $(80 \mu \mathrm{M})$ in $4 \mathrm{~T} 1$ cells. The inhibitors include nystatin for caveolae-mediated endocytosis, amiloride for micropinocytosis and chlorpromazine for clathrin-mediated endocytosis. Scale bar: $10 \mu \mathrm{m}$.

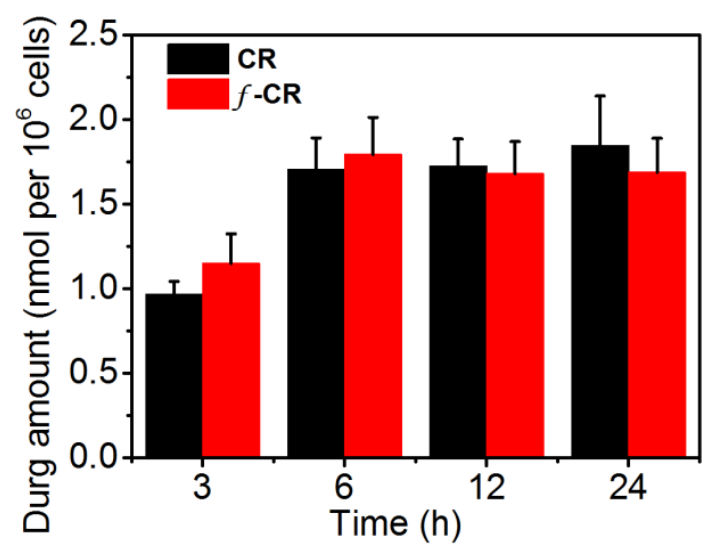

Figure S14. Cellular uptake of CR and $f$-CR at the dose of $80 \mu \mathrm{M}$ in $4 \mathrm{~T} 1$ cell after 3,6 , 12 and $24 \mathrm{~h}$ incubation, respectively. 


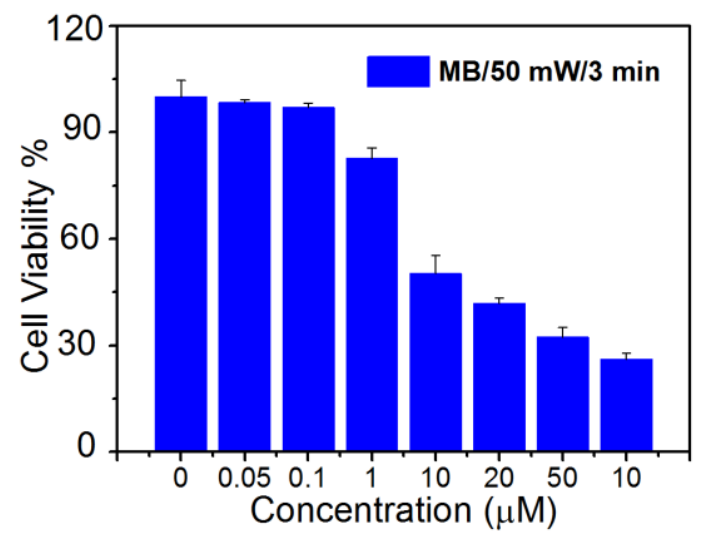

Figure S15. Cell viability of 4T1 cells treated with various doses of MB under $660 \mathrm{~nm}$ light irradiation (50 mW/cm², $3 \mathrm{~min})$.

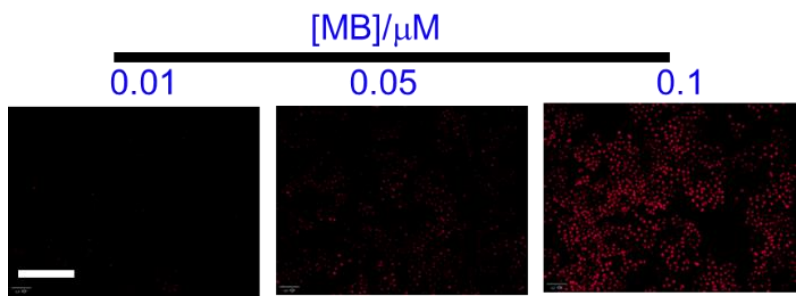

Figure S16. Fluorescent image of $4 \mathrm{~T} 1$ cells treated with $\mathrm{MB}$ at different doses $(0.01 \mu \mathrm{M}$, $0.05 \mu \mathrm{M}$, and $0.1 \mu \mathrm{M}$ ) under $660 \mathrm{~nm}$ irradiation ( $50 \mathrm{~mW} / \mathrm{cm}^{2}, 3 \mathrm{~min}$ ) and further stained by DHE assay (Scale bar: $500 \mu \mathrm{m}$ ). 


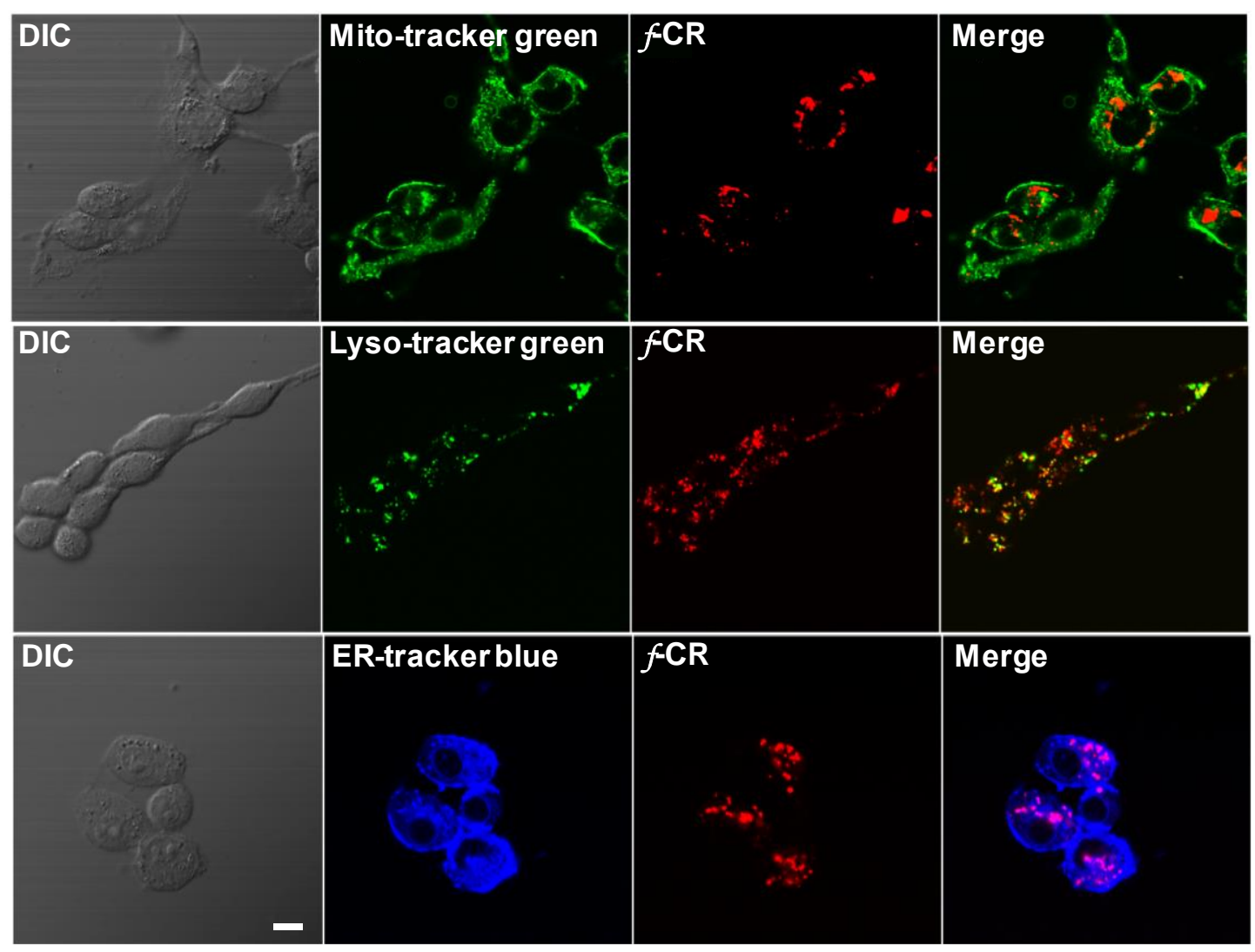

Figure S17. CLSM images of 4T1 cell incubated with $f$-CR $(20 \mu \mathrm{M})$ for $6 \mathrm{~h}$ and stained by Mito-tracker green, Lyso-tracker green and ER-tracker blue, respectively. Scale bar: $10 \mu \mathrm{m}$.
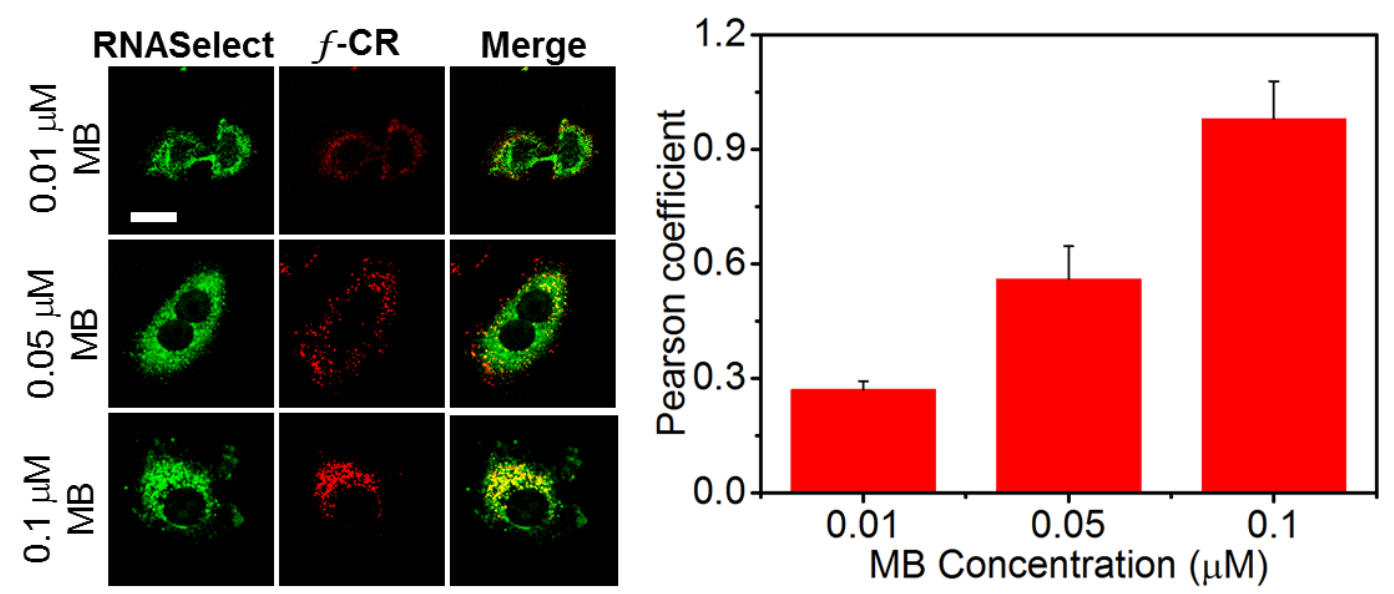

Figure S18. Confocal microscopy images (left) and pearson coefficient (right) of $4 \mathrm{~T} 1$ cells treated with $\mathrm{MB}$ at different dose $(0.01 \mu \mathrm{M}, 0.05 \mu \mathrm{M}$, and $0.1 \mu \mathrm{M})$ and $f-\mathrm{CR}(5 \mu \mathrm{M})$ under $660 \mathrm{~nm}$ irradiation (50 mW/cm², $3 \mathrm{~min}$ ) (Scale bar: $10 \mu \mathrm{m})$. 


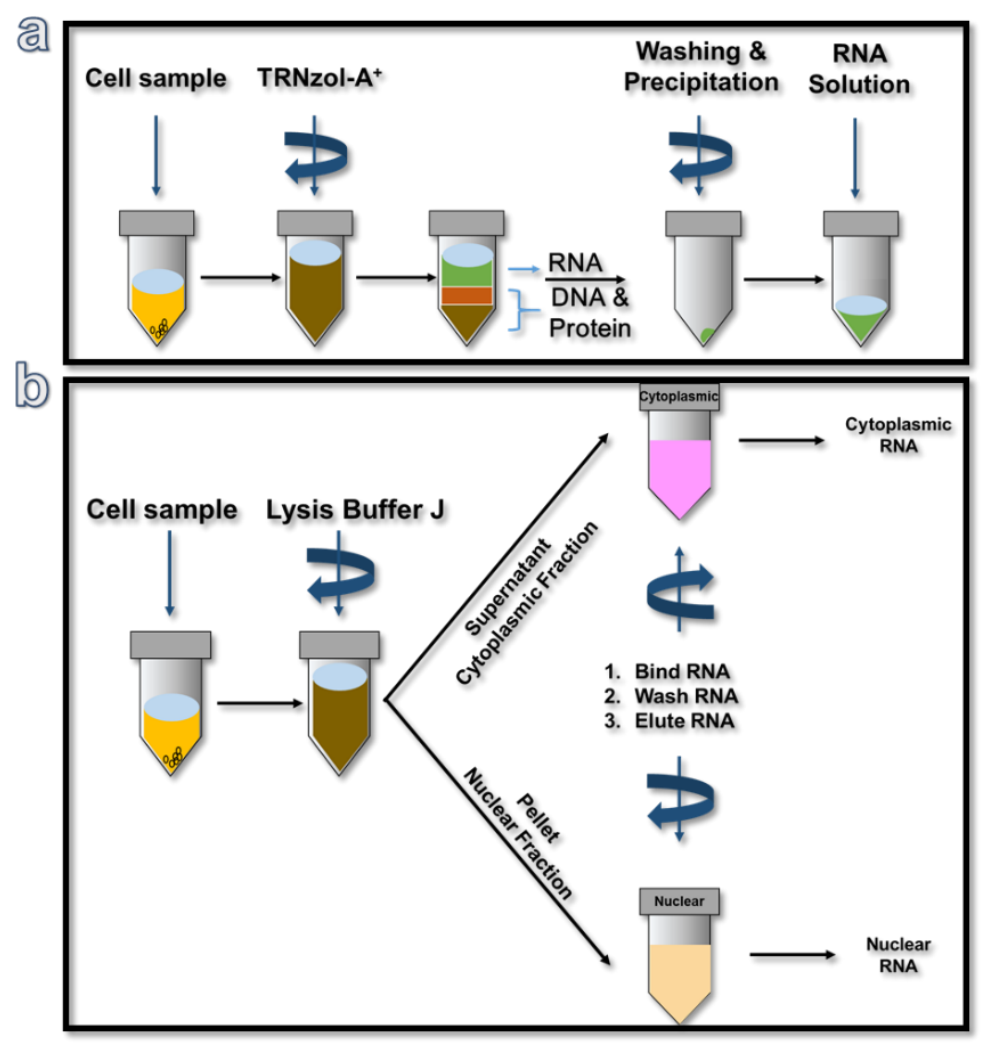

Scheme S2. The method of extracting cell total RNA using TRNzol- $\mathrm{A}^{+}$(a) and separately extracts cytoplasmic and nuclear RNA using RNA cytoplasm \& nucleus purification kit (b).

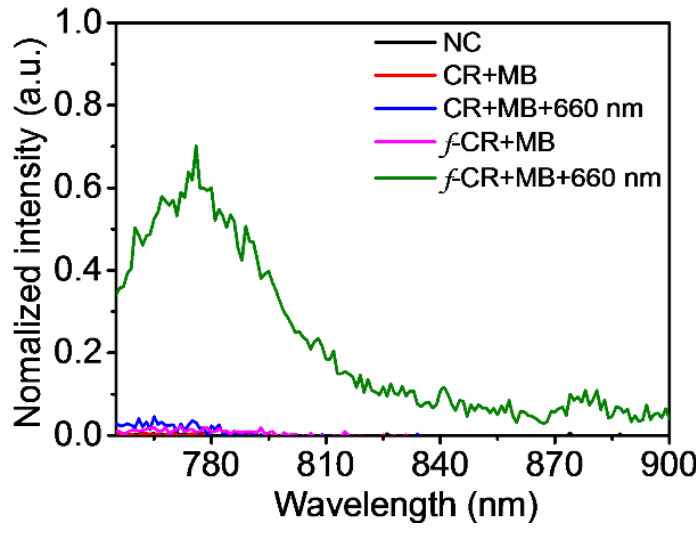

Figure S19. Fluorescence spectra of the cytoplasmic RNAs from different groups of cells. 


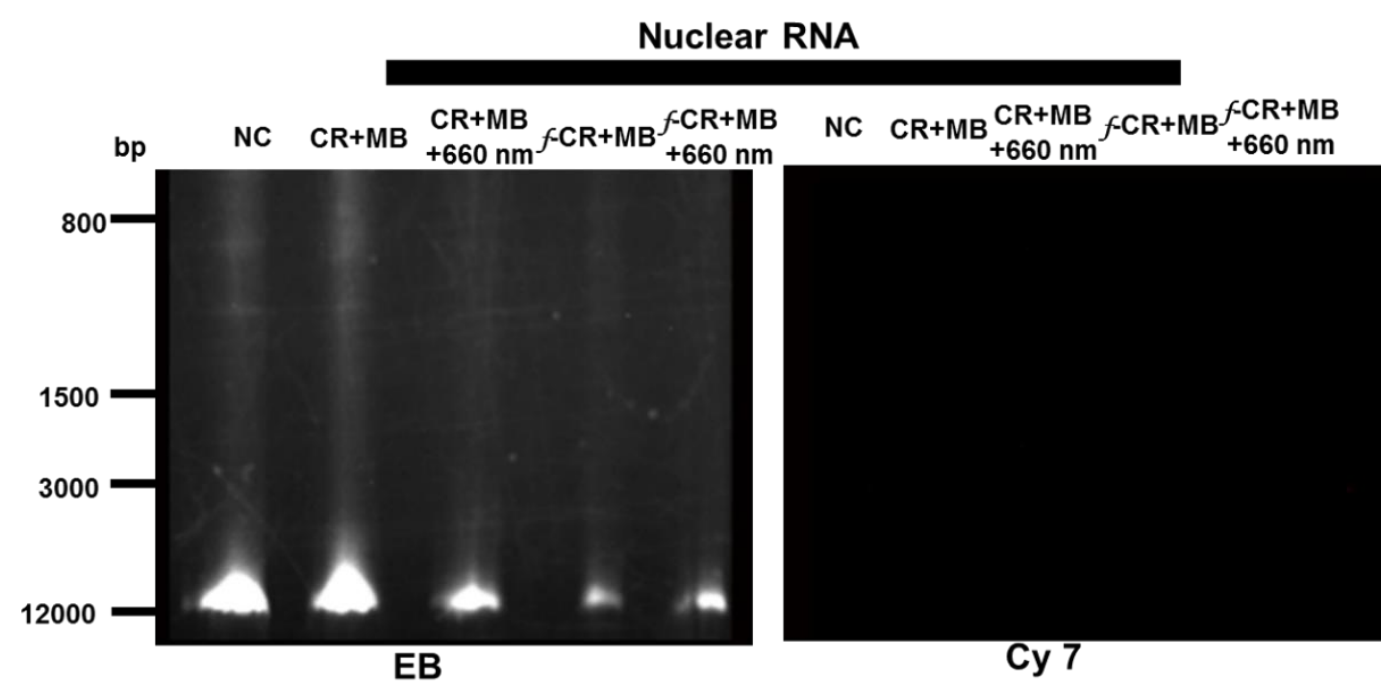

Figure S20. Fluorescence pictures of EB (left) and Cy7 (right) under gel electrophoresis of RNA extracted from the nucleus of $4 \mathrm{~T} 1$ cells by using Cytoplasmic \& Nuclear RNA Purification Kit.

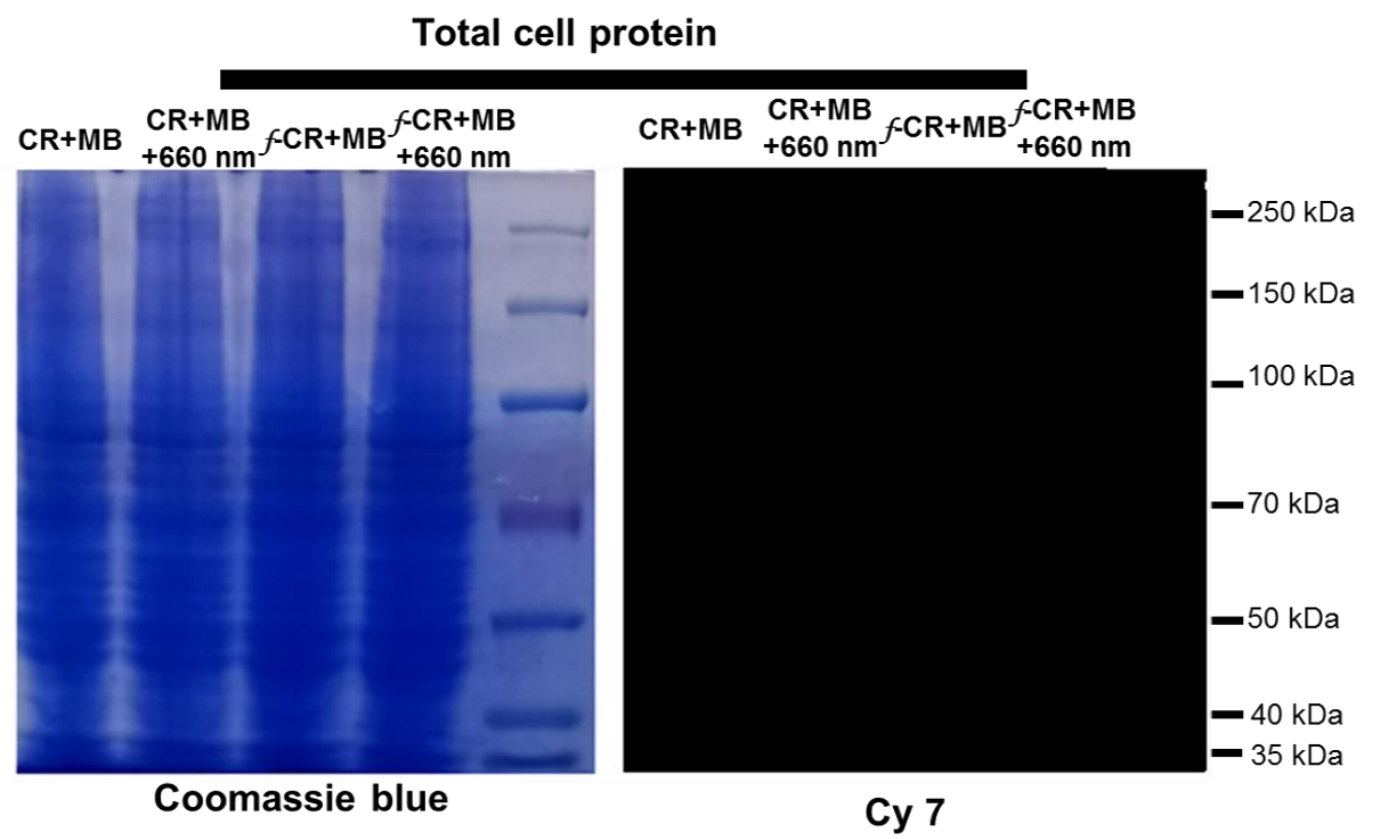

Figure S21. The PAGE gels of total proteins of $4 \mathrm{~T} 1$ cells under Coomassie blue (left) and Cy 7 (right). 


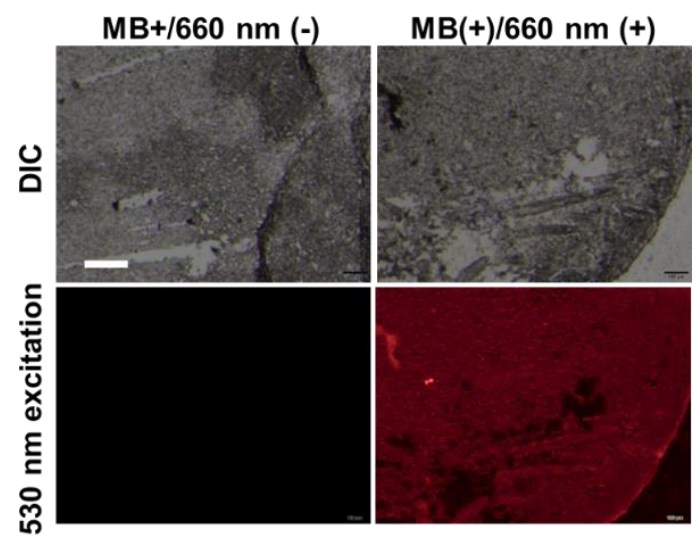

Figure S22. Fluorescence imaging of tumor section after intratumoral injection of $\mathrm{MB}(0.1$ $\mu \mathrm{M}, 50 \mu \mathrm{L})$ for $1.5 \mathrm{~h}$, then under the $660 \mathrm{~nm}\left(50 \mathrm{~mW} / \mathrm{cm}^{2}\right)$ irradiation for 3 min stained by DHE. (Scale bar: $200 \mu \mathrm{m})$.

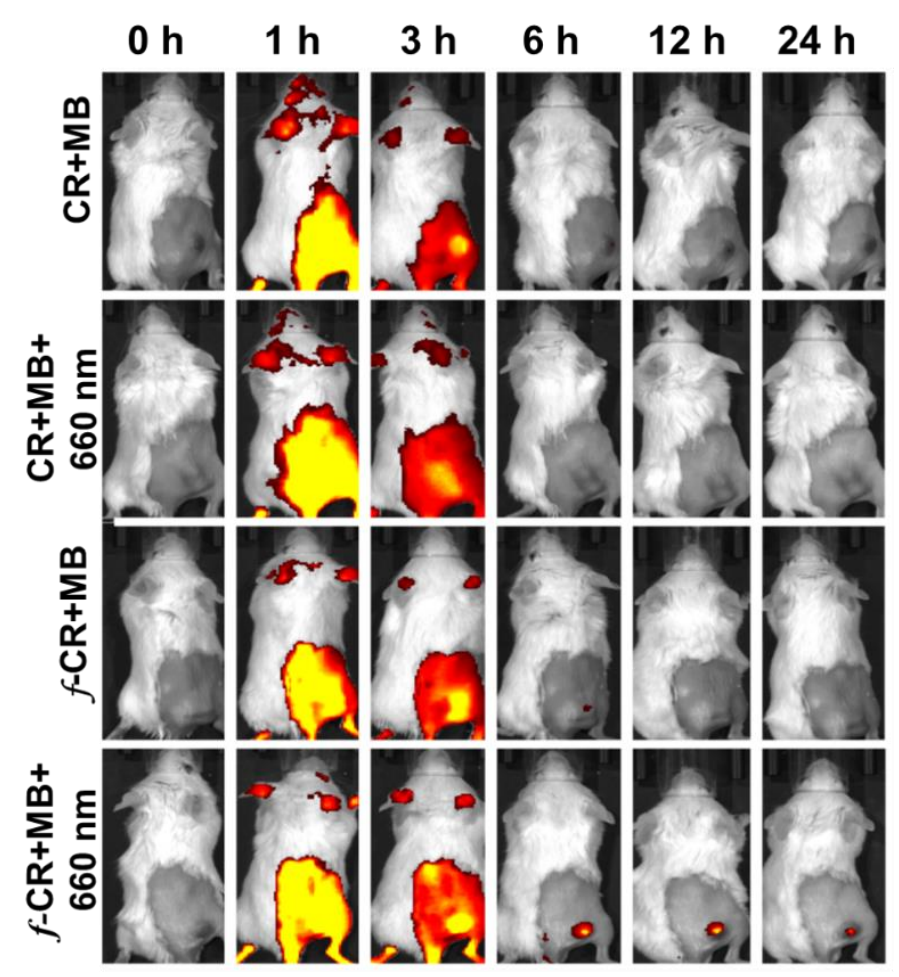

Figure S23. In vivo fluorescence images of subcutaneous 4T1 tumor-bearing Balb/c female mice with intratumoral pre-injection of $\mathrm{MB}(0.1 \mu \mathrm{M}, 50 \mu \mathrm{L})$ and intravenous injection $f$-CR or CR at dose of $100 \mu \mathrm{M}(200 \mu \mathrm{L})$, and followed by $660 \mathrm{~nm}$ irradiation $\left(50 \mathrm{mw} / \mathrm{cm}^{2}\right)$ for 3 min or not. 

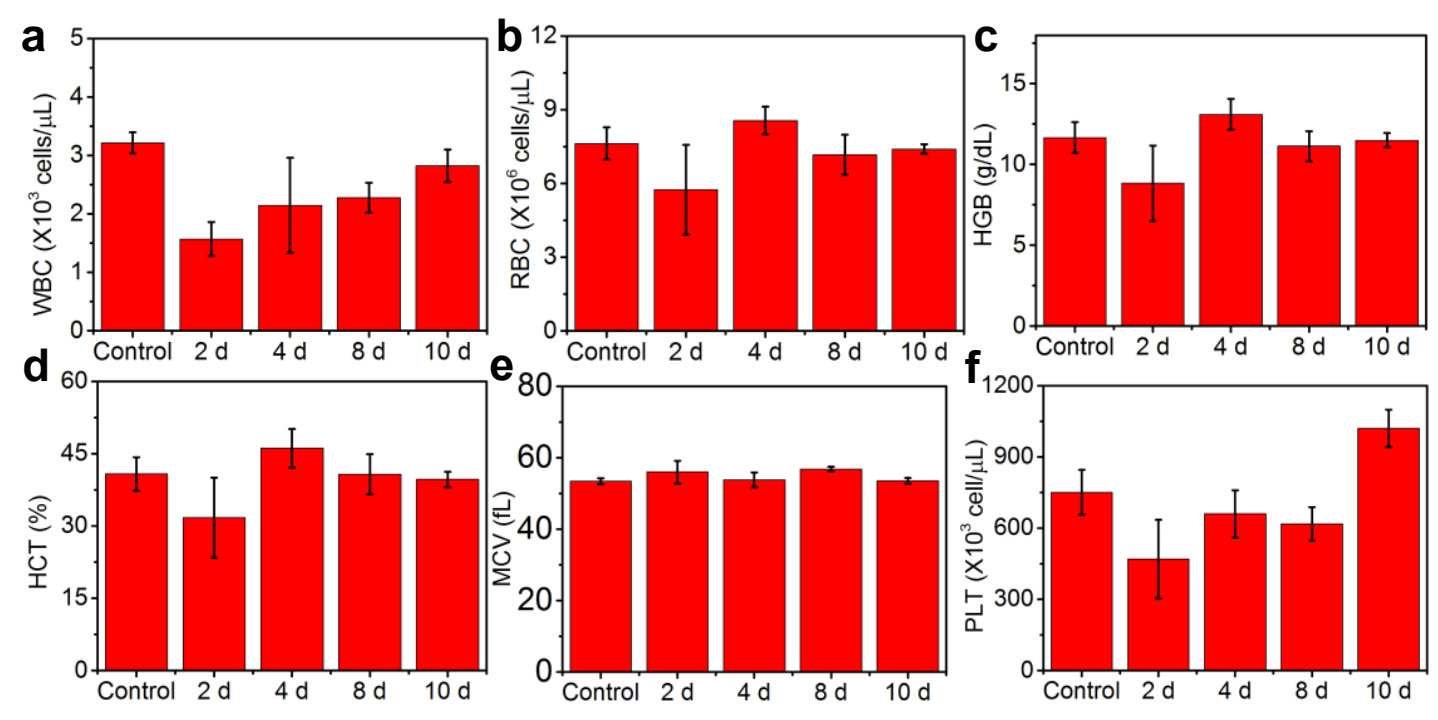

g

Heart

liver

Spleen

lung

Kidney

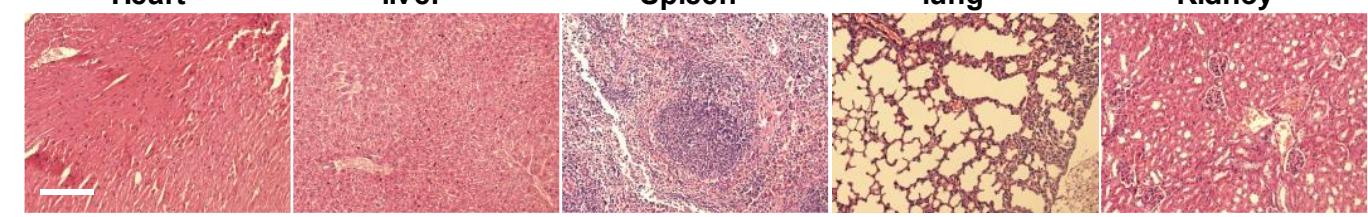

Figure S24. The blood index values after BALB/c mice injected with f-CR (500 mM, 200 $\mathrm{mL}$ ) including (a) white blood cell count (WBC), (b) red blood cell count (RBC), (c) hemoglobin (HGB), (d) hematocrit (HCT), (e) mean corpuscular volume (MCV), (f) platelets (PLT) $(n=3)$. (g)H\&E staining in main organs of representative mice captured on 10 days after injected with $f$-CR. Scale bar: $500 \mu \mathrm{m}$.

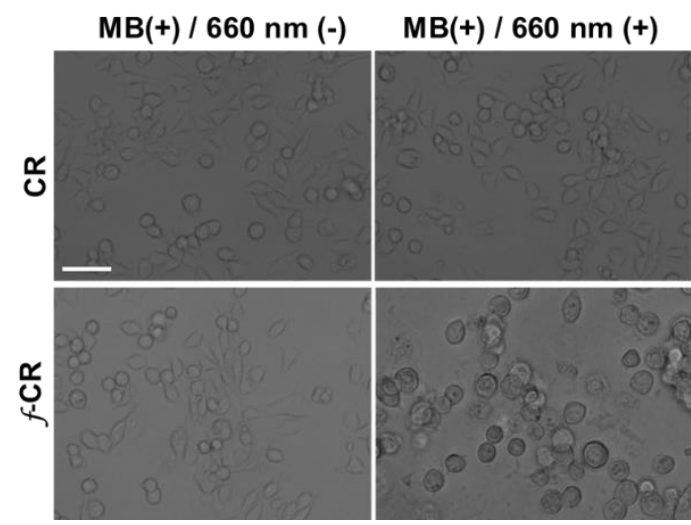

Figure S25. Live-cell differential interface contrast imaging of $4 \mathrm{~T} 1$ cells after treatment with $\mathrm{CR}, \mathrm{f}-\mathrm{CR}(30 \mu \mathrm{M})$ for $12 \mathrm{~h}$, then under the $660 \mathrm{~nm}$ irradiation $\left(50 \mathrm{~mW} / \mathrm{cm}^{2}\right)$ for $3 \mathrm{~min}$ and culture for further $48 \mathrm{~h}$. (Scale bar: $20 \mu \mathrm{m}$ ). 

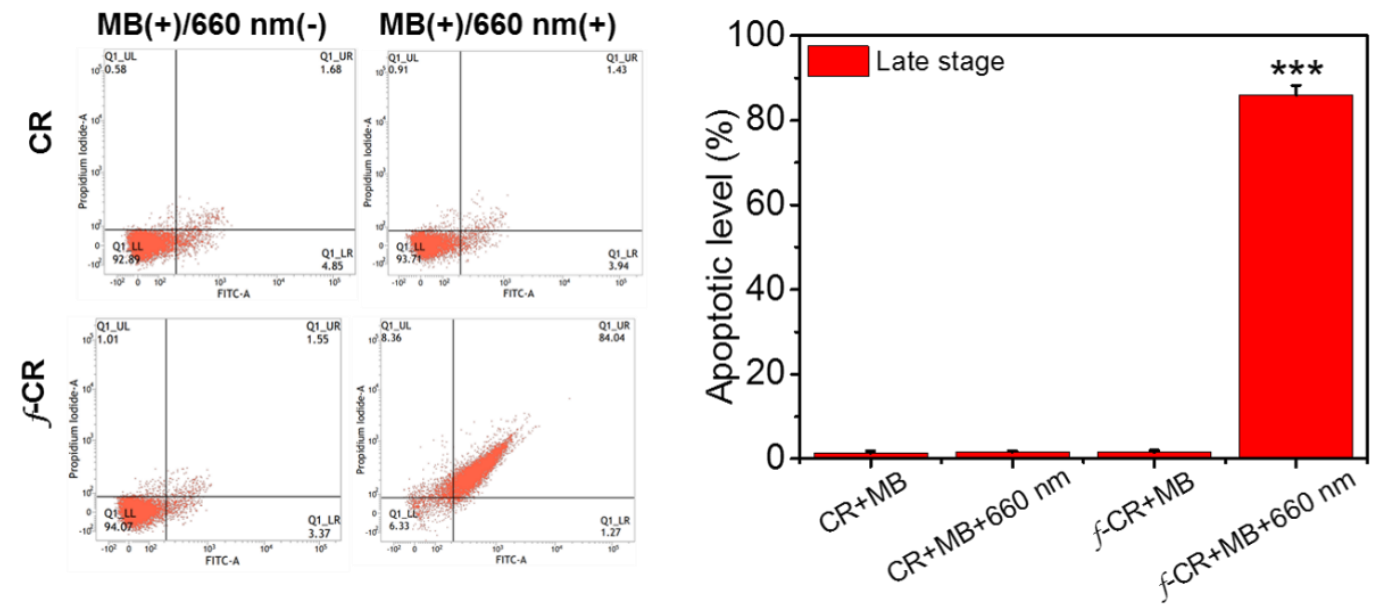

Figure S26. Flow cytometry imaging (left) and apoptosis level (right) of 4T1 cells with the treatment of CR, $f-C R(30 \mu \mathrm{M})$ for $12 \mathrm{~h}$, and then exposed to $660 \mathrm{~nm}$ irradiation (50 $\mathrm{mW} / \mathrm{cm}^{2}$ ) for $3 \mathrm{~min}$ followed by further $48 \mathrm{~h}$ culture.

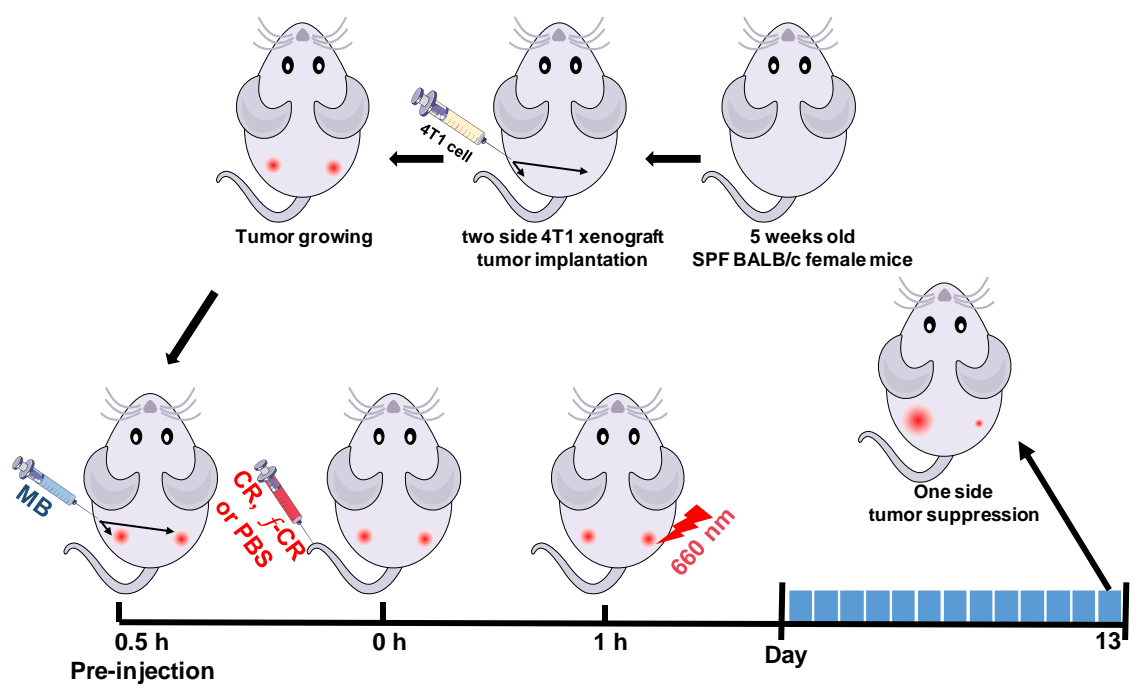

Scheme S3. Schematic illustration of the tumor suppression caused by the probe-RNA crosslinking. 


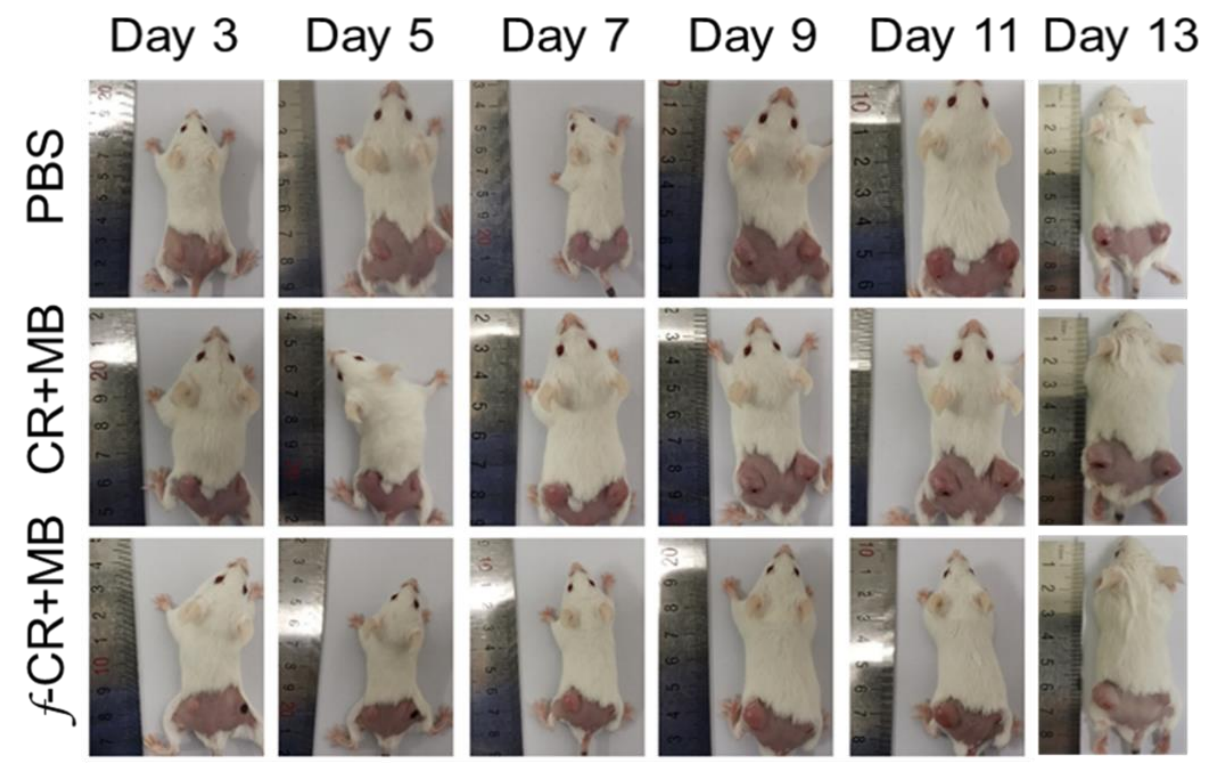

Figure S27. The mice photos of day 1, 3, 5, 7, 9, 11 after treatment.

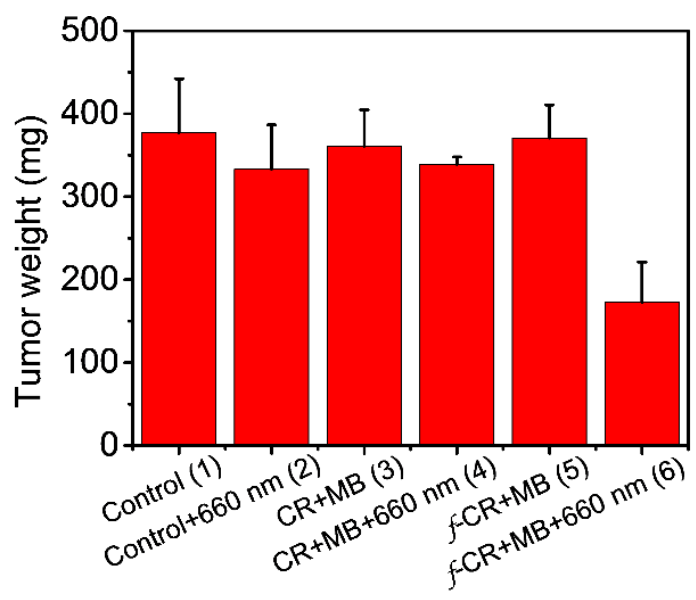

Figure S28. The average weight of various groups tumors after 13 days of treatment. 